\title{
Girls, Education, and Social Responsibility
}

\author{
Claudia Mitchell
}

\section{$\cos 80$}

\section{The Tribute}

With this issue of Girlhood Studies, we recognize the tenth anniversary of the death of Jackie Kirk, one of the co-founders of the journal. While we begin the issue with a visual essay "Honoring the Legacy of Jackie Kirk," in which we document a special international event that took place earlier this year that paid tribute to her work, as the other two co-founding editors of GHS, we, Claudia Mitchell and Jacqueline Reid-Walsh, would like to offer our own tribute to Jackie. As someone who travelled the globe, Jackie was a great emailer, and managed to remain connected to vast networks of researchers, practitioners, and members of NGOs regardless of where she was, and so it is perhaps fitting that we have found ourselves emailing back on forth about what we might say about her now.

Claudia recalls,

What is key for me is the memory of Jackie's amazing drive in connecting so many communities and being instrumental in setting up so many networks and partnerships. During the "Honoring the Legacy of Jackie Kirk" event described later in this issue what was so remarkable was that, ten years later, people were still confessing that they had had no idea that Jackie was collaborating with so many people at any one time and some people even thought that they were the only ones with whom she was working! From the beginning, Girlhood Studies has benefitted from so many of these connections; this journal is, in fact, more than just a journal in being, really, a whole community based on connections. The links currently being forged between the International Girls Studies Association (IGSA) and Girlhood Studies is part of this. And our managing editor, Ann Smith, so exemplifies this in encouraging new academics to review articles along with more experienced ones and in mentoring authors through the process of becoming published. Similarly, the entire team at Berghahn Press in New York is involved in building a community of authors and readers. 
Jacqui agreed,

Yes, I remember Jackie's energy and enthusiasm in forming and maintaining many different connections and you are right that Girlhood Studies has both benefitted from and extended this community in various ways. I remember her cheerful determination when we were thinking about starting a journal and then seeking a good publishing home for it. I think she would be pleased to see the journal at its eleven-year mark.

\section{The Articles}

While this is not an issue that had a thematic call, the articles here all relate to girls, education, and social responsibility, very much in keeping with Jackie Kirk's professional life, first as a primary school teacher in the UK and later as a champion of addressing education in emergencies, girls' education, and the lives of women teachers to name only three of her intersecting interests.

The first of our articles is by Lisa Smith and Stephanie Paterson whose "Guiding Girls: Neoliberal Governance and Government Educational Resource Manuals in Canada" sets the scene for an issue that has much to do with girls' education. In their analysis of Nova Scotia's Guide for Girls and Manitoba's 4 Girls Only! they illuminate "the ways in which young women, configured as "neoliberal subjects ... are increasingly expected to be autonomous and self-governing yet appear to require guidance to follow the right path towards future ideal neoliberal citizenship." These authors point out that it is girls' conduct that is seen to be problematic rather than "a variety of social problems such as poverty, unemployment, poor health, sexual violence, and stress" and they discuss the implications of this for "policy by, for, and about young women."

Joan Njagi then engages with the ways in which "hierarchical social relations ... and conservative religious and cultural norms [that] dictate appropriate expressions and experiences of sexuality for girls and young women" restrict the delivery of "sexual and reproductive health education to girls" in Kenya who use a children's helpline to seek information and guidance on matters relating to sexual health. She points out that the potential of such a revolutionary technology cannot be realized fully given the ways in which these "power dynamics and cultural norms" of Kenya operate to govern the expression of female sexuality.

In their article, “'Stumbling Upon Feminism': Teenage Girls' Forays into Digital and School-Based Feminisms," Crystal Kim and Jessica Ringrose discuss the ways in which "dismissive teacher and peer responses" pose a barrier 
to girls' use of "social media to combat sexism." They examine "a feminist society in a girls' secondary school in England" to show how, despite the encouraging increase in such societies in UK schools and "despite their multifaceted use of social media ... to combat sexism" these girls did not regard digital feminism as valid or worthwhile. The authors conclude that adult support for the cultivation of social media "as a legitimate pedagogical space" is essential "for youth engagement with social justice-oriented online content."

In the next article, "Something Good Distracts Us from the Bad:" Girls Cultivating Disruption," Crystal Leigh Endsley analyzes "the spoken word poetry of black, brown, and mixed-race high school girls in New Orleans, Louisiana" to showcase how these girls take up the challenge against "the powerful discourses that work to constrain them." She illustrates how the use of what she calls cultivated disruption in the poems of three girls, aged 14,15 , and 16 respectively, to "link instances of disruption highlighted through their poetry to aspects of their day-to-day experience" as they navigate their developing identities, shows that girls of color are "already practicing poetry as pleasurable and creative survival."

Jessica Prioletta then brings us back to Canada in her examination of how "the beliefs of preschool teachers that equality is the norm in their classrooms shape play periods in ways that may work to disadvantage girls." In "Unequal Education in Preschool: Gender at Play," we come to understand how "liberal notions of equality [reinforce] the traditional gender binary in children's play" because of the ways in which the equality discourses themselves work to obscure how girls are disadvantaged. Prioletta points out that this male-centered pre-school education must give way to an "ethics of care" if we are to attend successfully to this "gender binary in early learning."

The last two articles focus on girls and social responsibility. In "Girls' Work in a Rural Intercultural Setting: Formative Experiences and Identity in Peasant Childhood," Ana Padawer explores "the meaning of work for girls in rural northeastern Argentina as formative experience that forges their identity as peasants in the contemporary world. This author's interest in the ways in which young girls participate in the "social reproduction of families" is captured in the details of her ethnographic research on three peasant families. She warns us against romanticizing the participation of the girls in these activities ... as part of a socialization process" and makes it clear that this participation must be considered critically as "formative experience in which class, age, gender, and ethnic distinctions define certain tasks as girls' peasant skills." 
An examination of violent girls in Sweden for whom responsibility is related to both passivity and agency brings this section to a close. In "Being a Responsible Violent Girl? Exploring Female Violence, Self-management, and ADHD," Hanna Bertilsdotter Rosqvist and Linda Arnell draw our attention to "how young women in Sweden negotiate their gendered subject positions in relation to psychiatric diagnoses, particularly Attention Deficit Hyperactivity Disorder ... and the meanings of their own violent acts." Using discursive psychology, they see responsibility as being "connected to gendered notions of passivity and activity" and self-management. Their interest lies in how "the narratives of ADHD enable the understanding of an intelligible violent self, and therefore make female externalized violence what [they] describe as narrative-able."

Two book reviews round out this issue. In "Christianity and Sexuality: Girls and Women Forge New Paths," Sharon Woodill reviews Sonya Sharma's Good Girls, Good Sex: Women Talk about Church and Sexuality (2015) while in "Interrogating the Intersections of Girls and Sex," Hanna Retallack discusses Girls \& Sex: Navigating the Complicated New Landscape by Peggy Orenstein (2016). 